\title{
Neuropharmacological studies of ethanolic extract of Vaccinium corymbosum on Alzheimer's type dementia and catatonia in Swiss albino mice
}

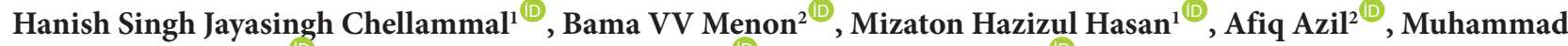 \\ Taufiq Bin Suhaimi $^{2}$, Pavithiraa Chandarasekaran ${ }^{2}$, Yasothini Murugan ${ }^{2}$ \\ ${ }^{1}$ Department of Pharmaceutical Pharmacology and Chemistry, Faculty of Pharmacy, Universiti Teknologi MARA, 42300 Puncak Alam, Selangor, \\ Malaysia \\ ${ }^{2}$ School of Pharmacy, KPJ Healthcare University College, Kota Seriemas, Nilai, Negeri Sembilan, 71800- Malaysia
}

\section{A R T I C L E I N F O}

Article Type:

Original Article

\section{Article History:}

Received: 15 August 2020

Accepted: 26 October 2020

\section{Keywords:}

Vaccinium corymbosum

Neurodegeneration

Behavioural changes

Alzheimer's disease

Aluminium

Neurotoxicity

\begin{abstract}
A B S T RA C T
Introduction: Neuroactive herbal drugs enriched with antioxidants are valuable in treating neurocognitive dysfunction and Vaccinium corymbosum, enriched with antioxidant phytochemicals, is used for treating memory disorders. Hence, the present study evaluated the neuroprotective effects of ethanolic extract of Vaccinium corymbosum (EEVC) on aluminium chloride $\left(\mathrm{AlCl}_{3}\right)$-induced Alzheimer's type of dementia and haloperidol-induced catalepsyassociated behavioural changes.

Methods: In vitro antioxidant potential was evaluated using 1-diphenyl-2-picrylhydrazyl (DPPH) and 2,2'-azino-bis (3-ethylbenzothiazoline-6-sulphonic acid) (ABTS). The total phenolic content (TPC) was quantified. For in vivo studies, $\mathrm{AlCl}_{3}(100 \mathrm{mg} / \mathrm{kg})$ was orally administered for 42 days, whereas the EEVC was administered on the $21^{\text {st }}$ day until the $42^{\text {nd }}$ day in two doses $(200 \mathrm{mg} / \mathrm{kg}$ and $400 \mathrm{mg} / \mathrm{kg})$. In the haloperidol-induced group, EEVC was treated for 21 days, and haloperidol ( $1 \mathrm{mg} / \mathrm{kg}$ ) was administered to induce behavioural changes. Open-field, Y-Maze and traction tests were performed, and the mice brain acetylcholinesterase (AChE) enzyme was determined.

Results: $\mathrm{IC}_{50}$ values in DPPH and ABTS assays were $85.5 \mu \mathrm{g} / \mathrm{mL}$ and $80 \mu \mathrm{g} / \mathrm{mL}$, respectively and the total phenolic content of EEVC was found to be $0.166 \mathrm{mg}$. In behavioural study, animals treated with $200 \mathrm{mg} / \mathrm{kg}$ and $400 \mathrm{mg} / \mathrm{kg}$ of EEVC exhibited a neuroprotective impact on $\mathrm{AlCl}_{3}$ induced neurodegeneration and haloperidol-induced behavioural changes with significant inhibition $(P<0.05$ and $P<0.01$, respectively) in acetylcholinesterase enzyme.

Conclusion: The neuroprotection by EEVC postulated that it is a promising therapeutic agent for treating behavioural and cognitive dysfunctions. Further investigations on proinflammatory cytokine and neuroendocrine regulation in transgenic Alzheimer's disease (AD) models complement the therapeutic value of $V$. corymbosum.
\end{abstract}

Implication for health policy/practice/research/medical education:

The neuroactive effect of Vaccinium corymbosum could be seen in $\mathrm{AlCl}_{3}$-induced neurodegeneration and haloperidol-induced behavioural changes. The potential antioxidant property and acetylcholinesterase-inhibitory effects of the ethanolic extracts of $V$. corymbosum played a pivotal role in the attenuation of behavioural changes and remarkably improved learning and memory. Hence, it might be beneficial in patients with Alzheimer's disease.

Please cite this paper as: Singh JCH, Menon VVB, Hasan MH, Azil A, Suhaimi MTB, Pavithiraa C, et al. Neuropharmacological studies of ethanolic extract of Vaccinium corymbosum on Alzheimer's type dementia and catatonia in Swiss albino mice. J Herbmed Pharmacol. 2021;10(2):241-248. doi: 10.34172/jhp.2021.27.

\section{Introduction}

Neurodegenerative diseases are characterised by the selective loss or dysfunction of particular neurons, and one of their key risk factors is the increase in age.
These diseases develop as a result of protein aggregates, inflammation, and oxidative stress in the central nervous system (CNS) (1,2). Neurodegenerative disorders have different characteristic symptoms in their initial phases: 
usually, cognitive decline, which could be related to the incidence of Alzheimer's disease (AD) or loss of motor control as the early indicators of Parkinson's disease or behavioural changes symptomatic of Huntington's disease $(3,4)$. Various biological mechanisms could be associated with neurodegeneration, such as oxidative stress, protein aggregation, neurotransmitter depletion or hyposecretion of neurotransmitters, metabolism of neurotransmitters in the synaptic cleft, mitochondrial dysfunction, neuronal excitotoxicity, and blood-brain barrier disruption (5). Aluminium is a widely found metal in the environment, food, water, and cooking vessels, which promote the chance of aluminium accumulation in the human body (6). This metal mainly targets the brain and escalates the neurofibrillary tangles and senile plaques that lead to dementia. It also causes oxidative damage to the cells upon its absorption into the CNS (7). Herbal plants contribute to various health benefits, such as antipsychotic, antifatigue, antidepressant, anxiolytic and hypnotics. Moreover, a wide variety of medicinal plants are wellknown for treating inflammation, neoplasia, arthritis, diabetes and hyperlipidemia. The herbal drugs that possess antioxidant benefits and are used for treating CNS disorders particularly provide neuroprotection in $\mathrm{AD}$ type of dementia. Patients with AD exhibit psychological alterations along with biological changes that can be associated with inflammation, oxidation, and infection (8-10).

Blueberry (Vaccinium corymbosum) from the Ericaceae family is cultivated for its valued dark-blue edible fruit, which is known to contain phenolic compounds that are documented to possess various health benefits. The raw extract of blueberry roots is antioxidant-enriched. Blueberry plants, especially the fruits enriched with polyphenols and flavonoids, involve in the curative activity of several diseases due to the presence of high phytoconstituents and antioxidant activity. The proposed applications include prevention and treatment of cancer, diabetes mellitus, cardiovascular diseases and neurodegenerative disorders (11-14). Blueberry might influence the health and well-being of the human system and also affords neuroprotection (15-18). The present study aimed to evaluate the neurobehavioural and neuroprotective effect of the fruit extract of $V$. Corymbosum on aluminium chloride $\left(\mathrm{AlCl}_{3}\right)$ - induced neurodegeneration and haloperidol-induced catalepsy in mice.

\footnotetext{
Materials and Methods

Drugs and chemicals

$\mathrm{AlCl}_{3}$, ethanol, 1,1-diphenyl-2-picrylhydrazyl (DPPH), Folin-Ciocalteu reagent, 2,2'-azino-bis (3-ethylbenzothiazoline-6-sulphonic acid) (ABTS), potassium persulfate, sodium carbonate $\left(\mathrm{Na}_{2} \mathrm{CO}_{2}\right)$, Ethylenediaminetetraacetic acid (EDTA) were purchased from the Merck company. Haloperidol was a gift sample
}

from KPJ Seremban of Specialist Hospital, Seremban, Malaysia. Acetylthiocholine iodide and 5,5'-dithio-bis[2-nitrobenzoic acid] (DTNB) were purchased from Alfa Aesar (Massachusetts, USA).

Fruit material and extraction

Fresh $V$. corymbosum fruits were obtained from a commercial vendor in Cheras, Kuala Lumpur. According to the macroscopic and microscopic characteristic features the fruits were authenticated by Dr. Mohd Firdaus Ismail, Biodiversity Unit, Institute of Bioscience, University Putra Malaysia. A voucher specimen was submitted to the department of Bioscience (Reference number: UPM/ IBS/UB/H61/17 and Voucher Number: SK 3220/17). Vaccinium corymbosum fruits weighing approximately $2 \mathrm{~kg}$ were dried under shade. Subsequently, it was homogenised with an appropriate amount of absolute ethanol (99.9\%), maintained at room temperature. After homogenisation, the ethanolic extracts of Vaccinium corymbosum (EEVC) were filtered and concentrated by processing me with a rotary vacuum evaporator. Next, the concentrated drug material was dried under silica gel and refrigerated to avoid microbial contamination (19).

\section{Determination of total phenol content}

Polyphenol content was estimated using the FolinCiocalteu method (20). Briefly, $1 \mathrm{~mL}$ extract was added to $5 \mathrm{~mL}$ of water and Folin's and was shaken for three minutes. After shaking, $2 \mathrm{~mL}$ of sodium carbonate was added and incubated for three hours. The absorbance was read at $760 \mathrm{~nm}$ using a UV-visible spectrophotometer (Shimadzu, Japan) with a solvent blank (distilled water). The polyphenol content was expressed as $\mathrm{mg}$ of gallic acid equivalent (GAE) per gram extract.

\section{Free radical scavenging ability on DPPH}

Free radical scavenging assay was determined using the DPPH method $(21,22)$ with a few modifications. Test samples were prepared and diluted to get five concentrations of $200,100,50,25$, and $10 \mu \mathrm{g} / \mathrm{mL}$ each, respectively. Then, $2 \mathrm{~mL}$ of different concentrations of the test solution (200, $100,50,25$, and $10 \mu \mathrm{g} / \mathrm{mL}$ ) were allowed to react with 1 $\mathrm{mL}$ of DPPH solution $(3.9 \mathrm{mg} / 10 \mathrm{ml}$ ethanol). The control sample consisted of a solution of $2 \mathrm{~mL}$ ethanol and $2 \mathrm{~mL}$ of DPPH, and ethanol served as blank. Using an ultra violet (UV)-visible spectrophotometer, the samples read at $517 \mathrm{~nm}$ after 30 minutes of incubation in dark at room temperature. The free radical scavenging capacity was compared to L-ascorbic acid and calculated the inhibition percentage.

\section{ABTS radical scavenging activity}

In this method, $9 \mathrm{mM}$ of ABTS stock reagent was used and the ABTS radical solution was prepared by reacting the stock solution with $2.45 \mathrm{mM}$ potassium persulphate (16 hours maintained at room temperature), and then 
diluted in ethanol $(1: 89 \mathrm{v} / \mathrm{v})$ and equilibrated to $30^{\circ} \mathrm{C}$ $(23,24)$. Next, $30 \mu \mathrm{L}$ of the extract was added into 3 $\mathrm{mL}$ of fresh ABTS radical solution and maintained at room temperature for 15 minutes. Subsequently, the absorbance value was read at $734 \mathrm{~nm}$ using the UV-visible spectrophotometer (Shimadzu, Japan). Moreover, $\mathrm{IC}_{50}$ was obtained by preparing a plot between percentage inhibition percentage versus concentration and expressed in $\mu \mathrm{g} / \mathrm{mL}$ equivalent to $\mathrm{L}$-ascorbic acid.

\section{Pharmacological studies}

\section{Selection and grouping of animals}

For this study, 48 Swiss male mice that weighed approximately 20-30 g each and aged 6-7 months old were selected. The animals were kept in an animal facility (Vivarium) called KPJ Healthcare University College, Kota Seriemas, Nilai, Negeri Sembilan at a temperature of $22 \pm 2{ }^{\circ} \mathrm{C}$ and 12 hours light/dark cycle. The study animals were divided into eight groups of 6 animals each. Four groups were selected for $\mathrm{AlCl}_{3}$-induced neurodegeneration studies, and the other four groups were selected for haloperidol-induced catalepsy. For $\mathrm{AlCl}_{3}$ induced neurodegeneration, group I A: control (normal saline-treated), group II A: negative control (treated with $\mathrm{AlCl}_{3}-100 \mathrm{mg} / \mathrm{kg}$ (oral)), group III A: treated with $\mathrm{AlCl}_{3}$ and $200 \mathrm{mg} / \mathrm{kg}$ of EEVC and group IV A: treated with $\mathrm{AlCl}_{3}$ and $400 \mathrm{mg} / \mathrm{kg}$ of EEVC were defined. The study period was 42 days, and $\mathrm{AlCl}_{3}$ was administered from the $1^{\text {st }}$ day until the $42^{\text {nd }}$ day orally before one hour of the EEVC treatment (21 days) (25). The EEVC treatment started from the $21^{\text {st }}$ day of the $\mathrm{AlCl}_{3}$ treatment. For haloperidol-induced studies, group I H: control (normal saline-treated), group II $\mathrm{H}$ : treated with haloperidol, group III H: treated with haloperidol and $200 \mathrm{mg} / \mathrm{kg}$ of EEVC and group IV H: treated with haloperidol and 400 $\mathrm{mg} / \mathrm{kg}$ of EEVC were defined. In the haloperidol-induced catalepsy group, the test drug (EEVC) was administered for 21 days and haloperidol $\left(1 \mathrm{mg} / \mathrm{kg}\right.$ ip) on the $21^{\text {st }}$ day. The pharmacological studies were performed 1 hour after the administration of haloperidol (26). The animals had access to water ad libitum and food pellets and were acclimatised for seven days before the experiments.

\section{Behavioural studies}

Open field test

The open field test (OFT), which provides a simultaneous measure of locomotion and exploration as the index of habituation memory, was used for this study. The apparatus was designed with a square arena $(50 \mathrm{~cm} \times 50$ $\mathrm{cm} \times 40 \mathrm{~cm}$ ) high with a black surface covering the wall. Each mouse was placed individually in the mid area of the square arena, and the spontaneous ambulatory locomotion of each animal for five minutes was quantified. The score accounted for the number of squares crossed, head dips and rearing were measured (27).

\section{$Y$-maze test}

The Y-maze test setup consisted of three arms and was placed in a horizontal position. Each arm (length: $40 \mathrm{~cm}$, width: $3 \mathrm{~cm}$, and wall height: $12 \mathrm{~cm}$ ) disposed at $120^{\circ}$ angles. The floor and walls were made of dark polyvinyl plastic. Initially, the mice were placed in one arm, and the sequence and numbers of arm entries were recorded for eight minutes (28). Consecutive entries into all three arms was an alternation index (For example, ABC, BCA, CAB).

Percentage alternation $=[($ Number of alternations $) /($ Total arm entries - 2)] x 100

\section{Traction test}

The apparatus was set up with three retort stands. Two retort stands were fixed parallel to each other, and the third retort stand was fixed horizontally between the two stands at a height of $40 \mathrm{~cm}$. The animal that was unsuccessful in making reestablishment with at least one of its posterior limbs to reach the bar was considered as exhibiting altered behaviour. The behaviours of animals were monitored, and the falling time was recorded during the experimental period (29).

\section{Biochemical studies \\ Determination of acetylcholinesterase}

The mouse brain was dissected out, rinsed with normal ice-cold saline before being dried and weighed. Then, $10 \%(\mathrm{w} / \mathrm{v})$ brain homogenate was prepared in an icecold medium [(1: $9 \mathrm{w} / \mathrm{v})$ of a $50 \mathrm{mM}$ phosphate-buffered saline (PBS) pH 7.0] and added $0.1 \mathrm{mmol} / \mathrm{L}$ EDTA. The homogenates were then subjected to centrifugation at 4000 RPM for 30 minutes at $4^{\circ} \mathrm{C}$ to prepare clear supernatants (10\%). Next, $0.1 \mathrm{~mL}$ of brain supernatants was added 6 $\mathrm{mL}$ of sodium phosphate buffer $(\mathrm{pH} 8)$, acetylthiocholine iodide $(0.2 \mathrm{~mL})$ and DTNB $(0.2 \mathrm{~mL}$-Ellman reagent). The absorbance of the solution was recorded at $412 \mathrm{~nm}$ (30).

\section{Statistical analysis}

The data were reported as mean \pm standard error mean (SEM). Statistical analysis was performed using one-way ANOVA test (followed Tukey's multiple comparison test). The value of $P<0.05$ was considered statistically significant. Graph Pad prism 7.0 was used as the application for the statistical analysis.

\section{Results}

Characteristics and percentage yield of extract The ethanolic extract was dark purple in colour. The consistency of the ethanolic extract of $V$. corymbosum was semi-solid with a uniquely pleasant aromatic odor. The yield in the percentage of ethanolic extract was $11.5 \%$.

Effect of EEVC on in vitro antioxidants

Total phenolic content

The TPC in the EEVC was $0.166 \mathrm{mg}$ GAE/g. The result 
was obtained from a calibration curve $(\mathrm{y}=0.003 \mathrm{x}+1.105$, $\mathrm{R}^{2}=0.996$ ) of GAE and was expressed to be equivalent to gallic acid.

\section{DPPH scavenging capacity}

The percentage inhibition of EEVC was 84.8 at $200 \mu \mathrm{g} / \mathrm{mL}$ when ascorbic acid was used as a reference. The $\mathrm{IC}_{50}$ of the EEVC extract was $85.5 \mu \mathrm{g} / \mathrm{mL}$, while that of ascorbic acid was $75 \mu \mathrm{g} / \mathrm{mL}$.

\section{ABTS radical scavenging activity}

The free radical scavenging activity in ABTS radical scavenging (\%) showed/demonstrated its antioxidant effect, and EEVC exerted an inhibition of 77.33 at $200 \mu \mathrm{g} /$ $\mathrm{mL}$. The absorbance at $734 \mathrm{~nm}$ indicated $\mathrm{R}^{2}$ of 0.995 . The $\mathrm{IC}_{50}$ value for EEVC was $80 \mu \mathrm{g} / \mathrm{mL}$ compared to that of ascorbic acid at $130 \mu \mathrm{g} / \mathrm{mL}$.

\section{Behavioural studies}

Open-field test

The studies measured head dipping, rearing and line crossing that indicated the improvement in cognitive function. The treatment with the EEVC demonstrated a significant effect, and the results have been shown in Table 1. For head dipping, the group II A animals (negative control) showed significant induction of memory loss compared to the group I A animals (control) by $P<0.01$ and signified the vigor of neurotoxicity. group III A and group IV A animals were administered EEVC with concentrations of $200 \mathrm{mg} / \mathrm{kg}$ and $400 \mathrm{mg} / \mathrm{kg}$, respectively. Both treatment groups exhibited a significant $(P<0.01)$ improvement in exploratory behaviour compared to group II A (negative). For line crossing, the neurodegenerationinduced group (group IIA) showed a decrease in exploratory behaviour $(P<0.05)$, as compared to the control group (group I A). The treatment group with a low dose of $200 \mathrm{mg} / \mathrm{kg}$ (group III) and $400 \mathrm{mg} / \mathrm{kg}$ (group IVA) exhibited significant improvement $(P<0.01$ and $P<0.001)$ in the line crossing activity. There was also a significant $(P<0.05)$ dose-dependent effect that was revealed in low-dose-treated animals (group III A, $200 \mathrm{mg} / \mathrm{kg}$ ) when compared to the high dose-treated animals (group IV A, $400 \mathrm{mg} / \mathrm{kg}$ ). The administration of $\mathrm{AlCl}_{3}$ decreased the number of rearing in the negative control group (group II) by $P<0.05$, compared to the control group (group I). The groups treated with $200 \mathrm{mg} / \mathrm{kg}$ (group III A) and $400 \mathrm{mg} / \mathrm{kg}$ (group IV A) EEVC exhibited a significant increase $(P<0.01$ and $<0.001$, respectively) in the number of rearing. In the haloperidol-induced catalepsy model study (Table 2), the EEVC low-dose treatment of $200 \mathrm{mg} /$ $\mathrm{kg}$ had a significant effect $(P<0.05)$ only for head dipping activity. In high-dose- $(400 \mathrm{mg} / \mathrm{kg})$ treated animals, all the parameters significantly improved, including rearing $(P<0.05)$, line crossing $(P<0.01)$ and head dipping $(P<0.01)$.

\section{Y-maze test}

With regard to spatial learning memory, the effects of EEVC treatment on percentage spontaneous alternation on the $\mathrm{AlCl}_{3}$ neurodegeneration group have been shown in Table 1. The percentage alternation in the $\mathrm{AlCl}_{3}$ induced group (group II A) was significantly decreased $(P<0.001)$ as compared to the normal group (group I A). In the treatment groups, the low dose and high dose of EEVC corresponding to $200 \mathrm{mg} / \mathrm{kg}$ (group III) and 400 $\mathrm{mg} / \mathrm{kg}$ (group IVA), respectively, were found to have a greater significant improvement in terms of percentage alternation with $P<0.001$, when compared with group II A animals (negative). Moreover, a greater significant dosedependent effect $(P<0.001)$ showed the group treated with a low dose of $200 \mathrm{mg} / \mathrm{kg}$ (group IIIA), compared to that with a high dose of $400 \mathrm{mg} / \mathrm{kg}$ (group IVA). In the haloperidol group, the negative control animals exhibited a significant reduction $(P<0.001)$ in percentage alternation, and in the treatment group, a significant increase $(P<0.001)$ in percentage alternation was noted only for the high-dose-treated animals (Table 2).

\section{Traction test}

The results of the traction test showed the effect of the EEVC treatment with regard to the enhancement of motor coordination and cognitive function on the mice. In the negative control group (group II A), the result of the traction test displayed a significant decrease $(P<0.05)$ in the motor function of the mice, which altered the reestablishment time when compared to group I A (control). The group treated with a low dose of EEVC at $200 \mathrm{mg} / \mathrm{kg}$ (group III A) exhibited a significant increase $(P<0.01)$ in motor coordination as indicated by the relatively high reestablishment time taken by the mice, while the group of animals treated with a high dose of EEVC at $400 \mathrm{mg} / \mathrm{kg}$ (group IVA) did not exhibit any significant alteration in terms of the reinstatement time. There was also a significant $(P<0.05)$ dose-dependent effect on animals treated with a low dose of $200 \mathrm{mg} / \mathrm{kg}$ (group III) when compared with those treated with a high dose of $400 \mathrm{mg} / \mathrm{kg}$ (group IV). The effects of the EEVC treatment on the motor coordination and movement ability of the mice have been presented in Table 1. For the haloperidol-induced group, there was a significant decrease $(P<0.01)$ in falling time after the administration of haloperidol in group II H. In the treatment groups, the low dose- (group IIIH) and high dose- (group IVH) treated animals exhibited a significant increase $(P<0.05)$ in falling time (Table 2).

Biochemical study

Acetylcholinesterase enzyme

The effect of EEVC treatment on acetylcholinesterase enzyme inhibition has been presented in Table 1 . In the $\mathrm{AlCl}_{3}$ neurodegeneration group, the inhibition 
Table 1. Effect of ethanolic extracts of Vaccinium corymbosum on behavioural studies and acetylcholinesterase enzyme in aluminium induced neurodegeneration in mice

\begin{tabular}{|c|c|c|c|c|c|c|}
\hline \multirow{2}{*}{ Group } & \multicolumn{3}{|c|}{ Open Field Exploration (counts/5 minutes) } & \multirow{2}{*}{$\begin{array}{l}\text { Y Maze } \\
\text { Percentage alternation }\end{array}$} & \multirow{2}{*}{$\begin{array}{l}\text { Traction test } \\
\text { Retention time (seconds) }\end{array}$} & \multirow{2}{*}{$\begin{array}{l}\text { AChE } \\
(\mu \mathrm{g} / \mathrm{min} / \mathrm{mg} \text { protein })\end{array}$} \\
\hline & Head dips & Rearing & Line crossings & & & \\
\hline I A (Control) & $51 \pm 3.05$ & $15 \pm 2.64$ & $134.7 \pm 17.4$ & $97.93 \pm 2.06$ & $18.67 \pm 1.76$ & $8.79 \pm 0.67$ \\
\hline II A $\left(\mathrm{AlCl}_{3}\right)$ & $5.33 \pm 0.33^{b}$ & $3 \pm 0.577^{c}$ & $74.67 \pm 8.81^{c}$ & $51.5 \pm 1.5^{\mathrm{a}}$ & $4.333 \pm 1.85^{c}$ & $16.85 \pm 1.17^{\mathrm{b}}$ \\
\hline III A $\left(\mathrm{AlCl}_{3}+200 \mathrm{mg} / \mathrm{kg} \mathrm{EEVC}\right)$ & $40 \pm 8.18^{e}$ & $24 \pm 3.60^{e}$ & $159 \pm 4.35^{\mathrm{e}}$ & $73.9 \pm 3.87^{e}$ & $8.00 \pm 1.155$ & $10.36 \pm 1.35^{c}$ \\
\hline IV A $\left(\mathrm{AlCl}_{3}+400 \mathrm{mg} / \mathrm{kg} \mathrm{EEVC}\right)$ & $48.33 \pm 5.45^{e}$ & $13.33 \pm 1.20^{f}$ & $221 \pm 12.70^{\mathrm{fg}}$ & $110.1 \pm 0.57^{e, h}$ & $22.33 \pm 4.09^{f . g}$ & $9.00 \pm 1.26^{e}$ \\
\hline
\end{tabular}

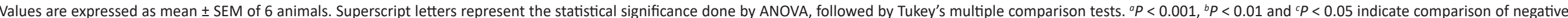

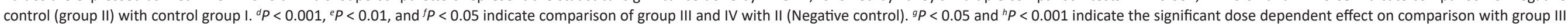
and group IV.

Table 2. Effect of ethanolic extracts of Vaccinium corymbosum on behavioural studies and acetylcholinesterase enzyme in Haloperidol induced neurodegeneration in mice

\begin{tabular}{|c|c|c|c|c|c|c|}
\hline \multirow{2}{*}{ Group } & \multicolumn{3}{|c|}{ Open Field Exploration (counts / 5 minutes) } & \multirow{2}{*}{$\begin{array}{l}\text { Y Maze } \\
\text { Percentage alternation }\end{array}$} & \multirow{2}{*}{$\begin{array}{l}\text { Traction test } \\
\text { Retention time (seconds) }\end{array}$} & \multirow{2}{*}{$\begin{array}{l}\text { AChE } \\
\text { ( } \mu \mathrm{g} / \mathrm{min} / \mathrm{mg} \text { protein) }\end{array}$} \\
\hline & Head dips & Rearing & Line crossings & & & \\
\hline I H (Control) & $15.75 \pm 1.49$ & $14.25 \pm 2.3$ & $108 \pm 2.48$ & $123.33 \pm 6.33$ & $77.00 \pm 11.88$ & $10.11 \pm 0.70$ \\
\hline III H (EEVC 200 mg/kg + Haloperidol) & $7.75 \pm 0.85^{c}$ & $10.75 \pm 2.49$ & $54.0 \pm 9.41$ & $69.83 \pm 5.76$ & $41.75 \pm 4.36^{c}$ & $14.00 \pm 1.91$ \\
\hline IV H (EEVC 400 mg/kg + Haloperidol) & $6.75 \pm 2.428^{d}$ & $14.00 \pm 2.55^{d}$ & $74.5 \pm 9.54^{d}$ & $98.50 \pm 9.35^{e}$ & $81.25 \pm 12.83^{c}$ & $13.33 \pm 1.20$ \\
\hline
\end{tabular}

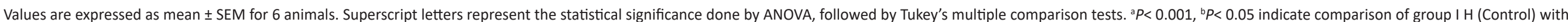
negative control (group IIH). ${ }^{\mathrm{C}} \mathrm{P}<0.05{ }^{\mathrm{d}} \mathrm{P}<0.01$ and ${ }^{\mathrm{e}} \mathrm{P}<0.001$ indicate comparison of group III H and IV H with group II H. 
was significant and indicated that there was a prompt acetylcholinesterase (AChE)-inhibitory effect. In the negative control group (group II A), in comparison with the control group (group I A), there was a significant increase $(P<0.01)$ in the level of enzymes, which indicated neurodegeneration. In the treatment group, the enzyme levels were found to be reduced, which was indicative of neuroprotection. The groups with EEVC doses of 200 and $400 \mathrm{mg} / \mathrm{kg}$ significantly exhibited the inhibition $(P<$ 0.05 and $P<0.01$ ), which indicated the neuroprotective effect, as compared to the negative control group. In the study group with haloperidol (Table 2), the AChE in the negative control group was slightly increased, and in treatment groups, a slight decline was noticed; however, no significant difference was observed.

\section{Discussion}

The present study investigated the neuroprotective effects of EEVC. Despite there being various studies on the effects of $V$. corymbosum extracts on learning $(15,31)$ and memory $(32,33)$, our study focused on the cognitive changes with regard to aluminium-induced neurodegeneration and haloperidol-induced catalepsy (mechanism of $\mathrm{AlCl}_{3}$ ). Memory impairment was significant after the exposure of $\mathrm{AlCl}_{3}$ to the mice, and it induced impaired performance in all the three behavioural parameters, including OFT, Y-Maze test and traction test. $\mathrm{AlCl}_{3}$ results in the disturbance of cholinergic neurotransmission and is linked to memory impairment $(34,35)$. The administration of EEVC in $\mathrm{AlCl}_{3}$-exposed animals proved that the drug is beneficial, and the animals exhibited improved learning, as evidenced by increased motor coordination or function, locomotion, exploration and cognition in all the three different behavioural studies. Primarily, the OFT was used as an indicator of exploratory tendencies in animal studies. The OFT is a test used to evaluate the emotionality of animals and entails subjecting an animal to an unfamiliar surrounding whose rescue is obstructed by enclosed walls (36). The Y-Maze test assesses the habituation, learning and spatial working memory. It evaluates the memory or cognitive functioning and the ability of the mice to explore new surroundings. The major brain regions involved in this test are the hippocampus, septum, basal forebrain and prefrontal cortex (37). The traction test measures motor coordination and movement ability that indicates the general neuronal function. The results from the EEVC treatment indicated that all three activities (line crossing, rearing, head dipping) of OFT, Y-Maze test and traction test exhibited significantly increased escalated performance in terms of learning and memory, which represented the neuroprotective effect. It was implied that various neurotransmitters and reactive oxygen species also play a role in the occurrence of haloperidol-induced toxicity. Due to the non-selective action of haloperidol on dopamine receptors and the blockade of post-synaptic D2 receptors in the nigrostriatal pathway, extrapyramidal side-effects developed (26,38-40). This might lead to altered behaviour, and studies have suggested that there is a significant negative impact on cognition with sustained attention, reaction time and information-processing speed. In our studies, it was found that the behavioural tests exhibited improved performance in haloperidol-induced catalepsy and behavioural changes. However, the low dose of EEVC did not exhibit behavioural improvement in memory; the high dose of EEVC significantly attenuated the haloperidol-induced impairment. Aluminium is a widely found metal and is known to cause $\mathrm{AD}$, which aggravates brain oxidative damage, induces inflammation and promotes $\mathrm{A} \beta$ deposition. It has been reported that the antioxidant activities of plants are promoted by phytoconstituents, such as polyphenolic and organic acids, and synergistic activity of various compounds. Studies have revealed that the polyphenolic compound exhibited antioxidant activity and is highly active in free radical scavenging (41). $V$. corymbosum is a fruit that has a high amount of flavonoids, tannins and phenolic acid (11, 13). The investigation in this study on in vitro antioxidant potency denoted a remarkable effect in scavenging the free radicals. $\mathrm{AlCl}_{3}$ increased the free radicals and induced escalation in the AChE enzyme to cause cognitive deficits in Alzheimer's type of dementia and altered the cholinergic function $(42,43)$. The present research indicated that there was an escalation in the $\mathrm{AChE}$ enzyme in $\mathrm{AlCl}_{3}$-induced neurotoxicity in the mice and the treatment with EEVC reversed AChE. However, no major changes were observed for the haloperidol-induced group. The promising effect on AChE inhibition as a result of EEVC treatment on $\mathrm{AlCl}_{3}$-induced neurodegeneration showcased a protective effect mediated through free radical scavenging potential and improved cholinergic turnover in the brain. In the present study, the antioxidant and neuroprotective activity of $V$. corymbosum was observed and correlated with the previous memory-related studies. It is necessary to conduct further study on the effects of $V$. corymbosum in the aspects of pro-inflammatory cytokines and neuroendocrine regulation in transgenic AD models.

\section{Conclusion}

In conclusion, the present study provided further evidence on the neuroprotective effect of $V$. corymbosum on $\mathrm{AlCl}_{3}$-induced cognitive dysfunction and haloperidolinduced mood changes in Swiss albino mice. The study demonstrated that the exhibited neuroprotective function was related to the AChE enzyme inhibition, free radical scavenging effect and might be caused by biogenic amine turnover. This research concluded that $V$. corymbosum could be a promising therapeutic agent for the treatment of cognitive dysfunction.

\section{Acknowledgments}

The authors would like to thank Dr. Vellayan Subramaniam, Faculty of Pharmacy, Universiti Teknologi 
MARA for the suggestions in animal experimentation and Dr. Mohd Firdaus Ismail, Biodiversity Unit, Institute of Bioscience, University Putra Malaysia. Authors also thank KPJ Healthcare University College for providing funds and facilities for conducting the study.

\section{Author's contributions}

HSJC designed and managed the study in terms of acquiring ethics permission. HSJC, MTS, AA, YM and PC carried out animal experimentations. HSJC, BVVM and $\mathrm{MHH}$ interpreted the results and drafted the article. All the authors reviewed the manuscript and offered opinions before submitting the final draft .

\section{Conflict of interests}

The authors declare no conflict of interest.

\section{Ethical considerations}

All experiments were conducted upon receiving the animal ethics committee's approval (Reference no: KPJUC/RIC/ BPS/EC/2017/58 and KPJUC/RMC/SOP/EC/2019/196). The implemented procedures completely adhered to the guidelines and protocol accorded by the ethics committee.

\section{Funding/Support}

The research was funded by KPJ Healthcare University College (253703-V- KPJUC/ RMC/ SOP/ EC/ 2019/ 196) Research Management Centre grant.

\section{References}

1. Lin MT, Beal MF. Mitochondrial dysfunction and oxidative stress in neurodegenerative diseases. Nature. 2006;443(7113):787-95. doi: 10.1038/nature05292.

2. Barnham KJ, Masters CL, Bush AI. Neurodegenerative diseases and oxidative stress. Nat Rev Drug Discov. 2004;3(3):205-14. doi: 10.1038/nrd1330.

3. Bancher $C$, Braak $H$, Fischer $P$, Jellinger KA. Neuropathological staging of Alzheimer lesions and intellectual status in Alzheimer's and Parkinson's disease patients. Neurosci Lett. 1993;162(1-2):179-82. doi: 10.1016/0304-3940(93)90590-h.

4. Weintraub D, Dietz N, Duda JE, Wolk DA, Doshi J, Xie SX, et al. Alzheimer's disease pattern of brain atrophy predicts cognitive decline in Parkinson's disease. Brain. 2012;135(Pt 1):170-80. doi: 10.1093/brain/awr277.

5. Liu Z, Zhou T, Ziegler AC, Dimitrion P, Zuo L. Oxidative stress in neurodegenerative diseases: from molecular mechanisms to clinical applications. Oxid Med Cell Longev. 2017;2017:2525967. doi: 10.1155/2017/2525967.

6. Tokutake S, Nagase H, Morisaki S, Oyanagi S. Aluminium detected in senile plaques and neurofibrillary tangles is contained in lipofuscin granules with silicon, probably as aluminosilicate. Neurosci Lett. 1995;185(2):99-102. doi: 10.1016/0304-3940(94)11234-a.

7. Mesole SB, Alfred OO, Yusuf UA, Lukubi L, Ndhlovu D. Apoptotic inducement of neuronal cells by Aluminium chloride and the neuroprotective effect of eugenol in Wistar rats. Oxid Med Cell Longev. 2020;2020:8425643. doi:
$10.1155 / 2020 / 8425643$.

8. Adams M, Gmünder F, Hamburger M. Plants traditionally used in age related brain disorders--a survey of ethnobotanical literature. J Ethnopharmacol. 2007;113(3):363-81. doi: 10.1016/j.jep.2007.07.016.

9. Tewari D, Stankiewicz AM, Mocan A, Sah AN, Tzvetkov NT, Huminiecki L, et al. Ethnopharmacological approaches for dementia therapy and significance of natural products and herbal drugs. Front Aging Neurosci. 2018;10:3. doi: 10.3389/fnagi.2018.00003.

10. Vyas S, Kothari SL, Kachhwaha S. Nootropic medicinal plants: therapeutic alternatives for Alzheimer's disease. J Herb Med. 2019;17-18:100291. doi: 10.1016/j. hermed.2019.100291.

11. Li D, Li B, Ma Y, Sun X, Lin Y, Meng X. Polyphenols, anthocyanins, and flavonoids contents and the antioxidant capacity of various cultivars of highbush and half-high blueberries. J Food Compost Anal. 2017;62:84-93. doi: 10.1016/j.jfca.2017.03.006.

12. Yamakawa MY, Uchino K, Watanabe Y, Adachi T, Nakanishi $\mathrm{M}$, Ichino $\mathrm{H}$, et al. Anthocyanin suppresses the toxicity of $\mathrm{A} \beta$ deposits through diversion of molecular forms in in vitro and in vivo models of Alzheimer's disease. Nutr Neurosci. 2016;19(1):32-42. doi: 10.1179/1476830515y.00 00000042.

13. Prior RL, Cao G, Martin A, Sofic E, McEwen J, O'Brien C, et al. Antioxidant capacity as influenced by total phenolic and anthocyanin content, maturity, and variety of vaccinium species. J Agric Food Chem. 1998;46(7):2686-93. doi: 10.1021/jf980145d.

14. Liu YH, Lin T, Ye CS, Zhang CQ. First report of fusarium wilt in blueberry (Vaccinium corymbosum) Caused by Fusarium oxysporum in China. Plant Dis. 2014;98(8):1158. doi: 10.1094/pdis-02-14-0167-pdn.

15. Hong SM, Soe KH, Lee TH, Kim IS, Lee YM, Lim BO. Cognitive improving effects by highbush blueberry (Vaccinium crymbosum L.) vinegar on scopolamineinduced amnesia mice model. J Agric Food Chem. 2018;66(1):99-107. doi: 10.1021/acs.jafc.7b03965.

16. Miller K, Feucht W, Schmid M. Bioactive compounds of strawberry and blueberry and their potential health effects based on human intervention studies: a brief overview. Nutrients. 2019;11(7). doi: 10.3390/nu11071510.

17. Seeram NP. Berry fruits: compositional elements, biochemical activities, and the impact of their intake on human health, performance, and disease. J Agric Food Chem. 2008;56(3):627-9. doi: 10.1021/jf071988k.

18. Ma L, Sun Z, Zeng Y, Luo M, Yang J. Molecular mechanism and health role of functional ingredients in blueberry for chronic disease in human beings. Int J Mol Sci. 2018;19(9). doi: 10.3390/ijms19092785.

19. Vinitha E, Singh HJC, Kakalij RM, Kshirsagar RP, Kumar BH, Diwan PV. Neuroprotective effect of Prunus avium on streptozotocin induced neurotoxicity in mice. Biomed Prev Nutr. 2014;4(4):519-25. doi: 10.1016/j.bionut.2014.08.004.

20. Žilić S, Basić Z, Hadži-Tašković Šukalović V, Maksimović V, Janković M, Filipović M. Can the sprouting process applied to wheat improve the contents of vitamins and phenolic compounds and antioxidant capacity of the flour? Int J Food Sci Technol. 2014;49(4):1040-7. doi: 10.1111/ijfs.12397. 
21. Haddadi-Guemghar H, Tlili A, Dairou J, Paul JL, Madani K, Janel N. Effect of lyophilized prune extract on hyperhomocysteinemia in mice. Food Chem Toxicol. 2017;103:183-7. doi: 10.1016/j.fct.2017.03.018.

22. Srividya AR, Dhanabal SP, Satish Kumar MN, Bavadia PKH. Antioxidant and antidiabetic activity of Alpinia galanga. Int J Pharmacogn Phytochem Res. 2011;3(1):6-12.

23. Michalska A, Wojdyło A, Łysiak GP, Figiel A. Chemical composition and antioxidant properties of powders obtained from different plum juice formulations. Int J Mol Sci. 2017;18(1). doi: 10.3390/ijms18010176.

24. Re R, Pellegrini N, Proteggente A, Pannala A, Yang M, RiceEvans C. Antioxidant activity applying an improved ABTS radical cation decolorization assay. Free Radic Biol Med. 1999;26(9-10):1231-7. doi: 10.1016/S0891-5849(98)003153.

25. Kasbe P, Jangra A, Lahkar M. Mangiferin ameliorates aluminium chloride-induced cognitive dysfunction via alleviation of hippocampal oxido-nitrosative stress, proinflammatory cytokines and acetylcholinesterase level. J Trace Elem Med Biol. 2015;31:107-12. doi: 10.1016/j. jtemb.2015.04.002.

26. Champatisingh D, Sahu PK, Pal A, Nanda GS. Anticataleptic and antiepileptic activity of ethanolic extract of leaves of Mucuna pruriens: a study on role of dopaminergic system in epilepsy in albino rats. Indian J Pharmacol. 2011;43(2):1979. doi: 10.4103/0253-7613.77368.

27. Singh HJ, Syeda TU, Kakalij RM, Prasad VV, Diwan PV. Erythropoietin protects polychlorinated biphenyl (Aroclor 1254) induced neurotoxicity in mice. Eur J Pharmacol. 2013;707(1-3):54-60. doi: 10.1016/j.ejphar.2013.03.009.

28. Jung WY, Kim H, Park HJ, Jeon SJ, Park HJ, Choi HJ, et al. The ethanolic extract of the Eclipta prostrata L. ameliorates the cognitive impairment in mice induced by scopolamine. J Ethnopharmacol. 2016;190:165-73. doi: 10.1016/j. jep.2016.06.010.

29. Alnamer R, Alaoui K, Bouidida el H, Benjouad A, Cherrah Y. Sedative and hypnotic activities of the methanolic and aqueous extracts of Lavandula officinalis from Morocco. Adv Pharmacol Sci. 2012;2012:270824. doi: $10.1155 / 2012 / 270824$.

30. Koladiya RU, Jaggi AS, Singh N, Sharma BK. Beneficial effects of donepezil on vascular endothelial dysfunctionassociated dementia induced by L-methionine in rats. J Health Sci. 2009;55(2):215-25. doi: 10.1248/jhs.55.215.

31. Choi YH, Kwon HS, Shin SG, Chung CK. Vaccinium uliginosum $\mathrm{L}$. improves amyloid $\beta$ protein-induced learning and memory impairment in Alzheimer's disease in mice. Prev Nutr Food Sci. 2014;19(4):343-7. doi: 10.3746/ pnf.2014.19.4.343.

32. Papandreou MA, Tsachaki M, Efthimiopoulos S, Klimis-
Zacas D, Margarity M, Lamari FN. Cell-line specific protection by berry polyphenols against hydrogen peroxide challenge and lack of effect on metabolism of amyloid precursor protein. Phytother Res. 2012;26(7):956-63. doi: 10.1002/ptr.3670.

33. Ramirez MR, Izquierdo I, do Carmo Bassols Raseira M, Zuanazzi JA, Barros D, Henriques AT. Effect of lyophilised Vaccinium berries on memory, anxiety and locomotion in adult rats. Pharmacol Res. 2005;52(6):457-62. doi: 10.1016/j.phrs.2005.07.003.

34. Singh T, Goel RK. Neuroprotective effect of Allium сера L. in aluminium chloride induced neurotoxicity. Neurotoxicology. 2015;49:1-7. doi: 10.1016/j. neuro.2015.04.007.

35. Al-Amin MM, Reza HM, Saadi HM, Mahmud W, Ibrahim AA, Alam MM, et al. Astaxanthin ameliorates aluminum chloride-induced spatial memory impairment and neuronal oxidative stress in mice. Eur J Pharmacol. 2016;777:60-9. doi: 10.1016/j.ejphar.2016.02.062.

36. Rebai O, Djebli NE. Chronic exposure to aluminum chloride in mice: exploratory behaviors and spatial learning. Adv Biol Res. 2008;2(1-2):26-33.

37. Kassa J, Bajgar J, Kuca K, Jun D. Behavioral toxicity of nerve agents. In: Handbook of Toxicology of Chemical Warfare Agents. Elsevier; 2015. p. 477-87. doi: 10.1016/B978-0-12800159-2.00035-X.

38. Bhattacharya SK, Bhattacharya D, Sairam K, Ghosal S. Effect of Withania somnifera glycowithanolides on a rat model of tardive dyskinesia. Phytomedicine. 2002;9(2):16770. doi: 10.1078/0944-7113-00089.

39. Sanberg PR. Haloperidol-induced catalepsy is mediated by postsynaptic dopamine receptors. Nature. 1980;284(5755):472-3. doi: 10.1038/284472a0.

40. Nair V, Arjuman A, Gopalakrishna HN, Nandini M. Effect of Withania somnifera root extract on haloperidol-induced catalepsy in albino mice. Phytother Res. 2008;22(2):243-6. doi: 10.1002/ptr.2299.

41. Cassidy L, Fernandez F, Johnson JB, Naiker M, Owoola AG, Broszczak DA. Oxidative stress in alzheimer's disease: a review on emergent natural polyphenolic therapeutics. Complement Ther Med. 2020;49:102294. doi: 10.1016/j. ctim.2019.102294.

42. Cheng XJ, Gu JX, Pang YP, Liu J, Xu T, Li XR, et al. TacrineHydrogen Sulfide Donor Hybrid Ameliorates Cognitive Impairment in the Aluminum Chloride Mouse Model of Alzheimer's Disease. ACS Chem Neurosci. 2019;10(8):35009. doi: 10.1021/acschemneuro.9b00120.

43. Prakash D, Sudhandiran G. Dietary flavonoid fisetin regulates aluminium chloride-induced neuronal apoptosis in cortex and hippocampus of mice brain. J Nutr Biochem. 2015;26(12):1527-39. doi: 10.1016/j.jnutbio.2015.07.017. 